\title{
Landscape analysis of the family planning situation in Pakistan-District profile: Rawalpindi
}

Population Council

Follow this and additional works at: https://knowledgecommons.popcouncil.org/departments_sbsr-rh

Part of the Demography, Population, and Ecology Commons, Family, Life Course, and Society Commons, International Public Health Commons, and the Rural Sociology Commons How does access to this work benefit you? Let us know!

\section{Recommended Citation}

"Landscape analysis of the family planning situation in Pakistan-District profile: Rawalpindi." Islamabad: Population Council, 2016. 


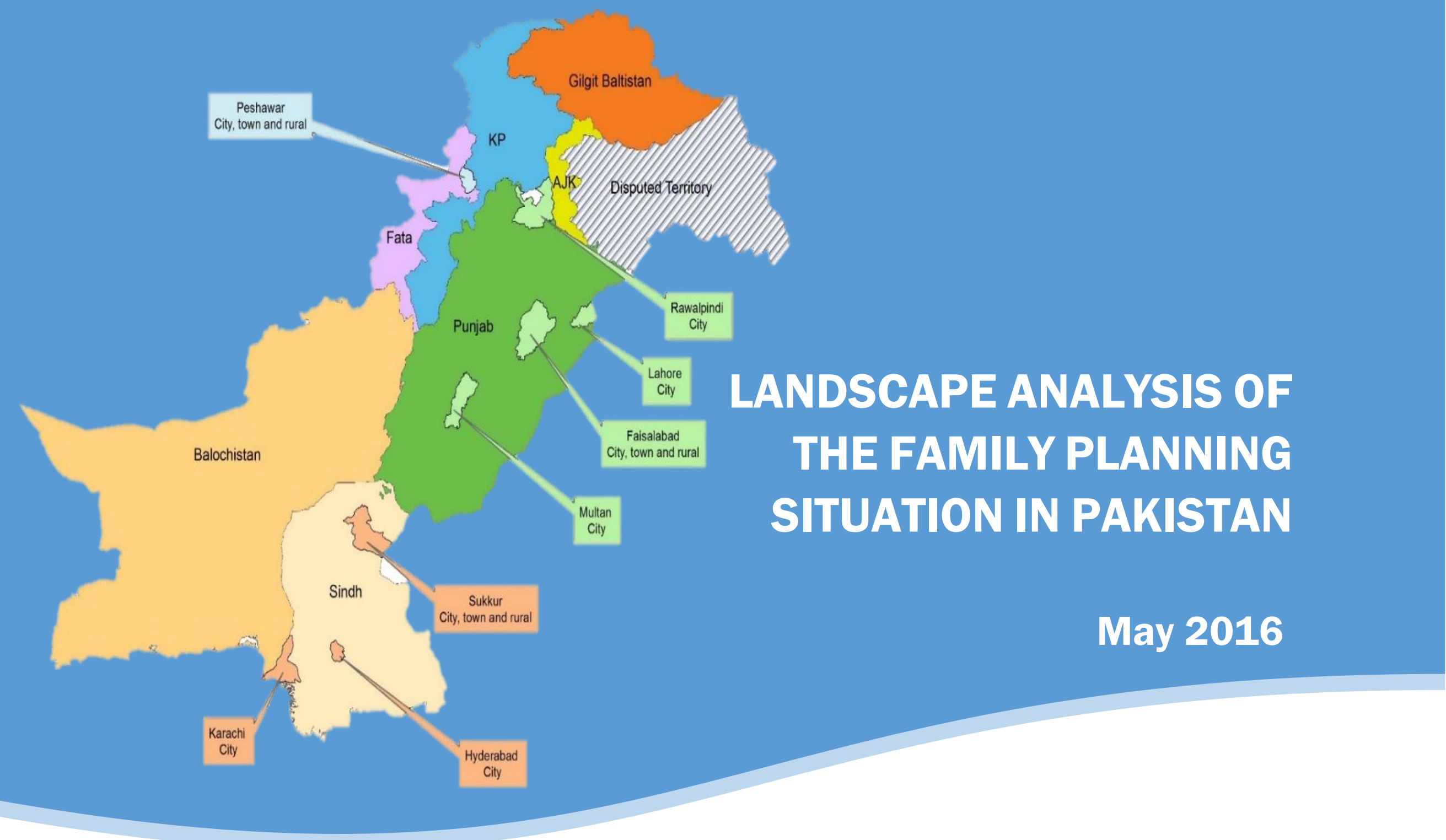

\section{DISTRICT PROFILE: RAWALPINDI}

BILL $\&$ MELINDA

GATES foundation 


\section{Background}

Rawalpindi is situated in northern Punjab. It has an estimated population of 4.7 million $^{1}$ and consists of nine administrative strata, including eight towns and one cantonment area (Figure 1). Table 1 presents key demographic facts about the district. Around 56 percent of the population resides in urban areas. Of the estimated 0.7 million married women of reproductive age (MWRA) in the district, 0.4 million live in urban areas.

Table 1: Demographics of Rawalpindi

\begin{tabular}{|l|l|l|l}
\hline Demographics & Urban & Rural & Overall \\
\hline Total population & $2,622,000$ & $2,069,000$ & $4,691,000$ \\
\hline Women 15-49 & 712,000 & 548,000 & $1,260,000$ \\
\hline MWRA & 392,000 & 349,000 & 741,000 \\
\hline $\begin{array}{l}\text { Literacy rate (10 years and } \\
\text { above), * }\end{array}$ & $86 \%$ & $80 \%$ & $83 \%$ \\
\hline IMR** & - & - & 53 \\
\hline TFR** & - & - & 3.1
\end{tabular}

Source: Punjab Development Statistics 2015, * Pakistan Social and Living

Standards Measurement Survey (PSLMS) 2014-15, ** Multiple Indicator Cluster Survey Punjab (MICS) 2014

Rawalpindi's total fertility rate (TFR), at 3.1, is below Punjab's average TFR of 3.5. The infant mortality rate is also low compared to other study districts.

\section{Use of Antenatal and Delivery Care Services}

The majority of women in Rawalpindi sought antenatal health care from a skilled provider during their last pregnancy (94\%). ${ }^{2}$ In both urban and rural areas, government facilities are the major source of antenatal
Figure 1: Map of Rawalpindi District

\section{Map of Punjab Province}

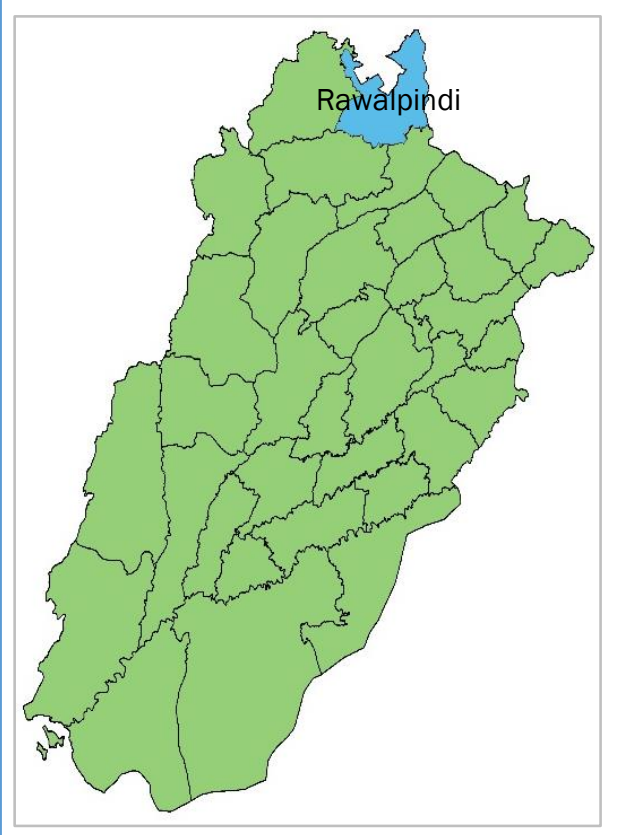

\section{Map of Rawalpindi District}

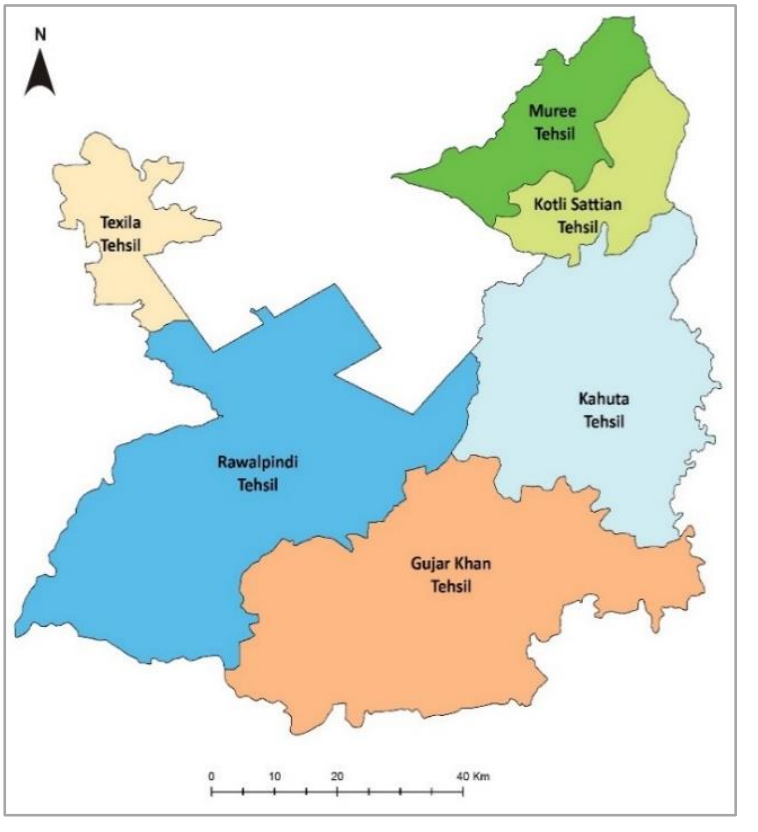

health care, followed by private hospitals or clinics. The most common places of delivery in urban areas are private hospitals or clinics (39\%), followed by government facilities (34\%). However, in rural areas, most deliveries take place at government health facilities (47\%). 


\section{Use of Family Planning}

The contraceptive prevalence rate in Rawalpindi is 43.2 percent, ${ }^{3}$ higher than Punjab's average of 38.7 percent. However, this includes high use of traditional methods, both in urban and rural areas. Interestingly, traditional method use is much higher in urban areas than in rural areas, and underlies the much higher urban CPR (Table 2). Unmet need is 15.8 percent, a bit higher in rural than in urban areas.

Table 2: Contraceptive Use and Unmet Need

\begin{tabular}{|c|c|c|c|c|}
\hline \multirow[b]{2}{*}{ District } & \multicolumn{3}{|c|}{ Contraceptive Prevalence Rate (CPR) } & \multirow[b]{2}{*}{$\begin{array}{l}\text { Unmet } \\
\text { need }\end{array}$} \\
\hline & $\begin{array}{l}\text { Any } \\
\text { Method }\end{array}$ & $\begin{array}{l}\text { Traditional } \\
\text { Methods }\end{array}$ & $\begin{array}{l}\text { Modern } \\
\text { Methods }\end{array}$ & \\
\hline Rawalpindi & 43.2 & 8.0 & 35.2 & 15.8 \\
\hline Urban & 48.6 & 9.8 & 38.8 & 15.3 \\
\hline Rural & 36.9 & 5.9 & 31.1 & 16.4 \\
\hline
\end{tabular}

Source: Multiple Indicator Cluster Survey Punjab (MICS) 2014

\section{Other Socio-economic Indicators}

The literacy rate (10 years and above) in Rawalpindi is as high as 83 percent, with the rural literacy rate just 6 percentage points lower than the urban literacy rate (86\%). Female literacy is lower in both urban and rural areas.

The majority of households own a television set, both in urban (92\%) and rural areas (84\%). Mobile or landline phones are owned by the vast majority of households (96\%).

Most houses have reinforcement of concrete and cement (RCC) or reinforcement of brick and cement (RBC) roofs in urban (96\%) as well as rural areas $(60 \%)$, and similarly, in both urban and rural settings, burnt bricks or blocks are used as the main material for house walls. These indicators show the majority of households have fairly good socio-economic conditions, mainly in urban areas.

\section{Consumer Perspectives on Barriers to Use of Family Planning}

During the landscape assessment, a total of 9 in-depth interviews were conducted in Rawalpindi, including 6 with women and 3 with men, in addition to 3 focus group discussions with men and women. A total 37 men and women participated in discussions from this study district, and were asked about the barriers they encounter in using family planning services.

Three strong barriers to use of family planning were identified, including lack of information on family planning; problems in accessing services, among the rural poor; and cost of services, among poor couples in both urban and rural areas.

\section{Lack of information among men and women, especially migrants}

- Lack of information is a major barrier for both men and women in the district.

- While there are multiple choices of services available in urban areas, the Pathan migrants who reside in the district follow their own traditions and women's mobility is restricted; they cannot go alone outside, and have no information regarding family planning.

- LHWs visit these migrants, but only to dispense polio drops and not to provide family planning services.

- As in other areas, cultural norms discourage men from discussing family planning matters with other men, so they do not have any direct source of information.

"There are opportunities but we do not go outside. We consult private doctors to get information about family planning. The LHW visits only for polio vaccination." Female, Rawalpindi city

"Currently I am forced to use this method (oral contraceptive pills) because I don't know about the availability of any other suitable method. I feel that this method is also affecting my health." Female, Rawalpindi city 


\section{Problems of access among poor rural women}

- Low access to health facilities is a major challenge for poor rural women in the district.

•

- Mostly, women receive contraceptives (OCP, condoms, and injectables) from LHWs in rural areas.

- For other methods, facilities are not located nearby; to get IUDs, women go to public facilities and have to pay high travel fares.

- Low accessibility is also a barrier for rural women in getting treatment for side effects of FP methods

"Mainly the LHW provides contraceptives but for other health issues people have to travel 40 kilometers to hospitals." Male, Rawalpindi rural

"Hospitals are located far away from this area. Local private clinics and BHUs are at half an hour's walking distance and hospitals with better services, such as PIMS, are too far from here." Female, Rawalpindi rural

"A facility should be there within this area. Because I have young children, I am unable to spare the time to go to the hospital, which is far away. The government should open a dispensary or center in every locality to provide FP services to people." Female, Rawalpindi rural

\section{Difficulty in affording services, among poor couples}

- Costs of services and contraceptives are a major barrier for poor couples in both urban and rural areas.

- Mostly, women get contraceptives from LHWs but in a stock-out situation, they have to buy products from the market, which is difficult for the poor.

- Bearing the costs of managing side effects of contraceptives is also a barrier for poor couples.

- Public facilities provide FP services free of cost, but travel fares still pose a hurdle for the rural poor.

"I get pills from the LHW. Twice, I got them from the market (I think the price was less them 100 rupees). It is difficult for us to pay." Female, Rawalpindi city

"Though I got the IUD from a public hospital, I had to spend 800 rupees on travel to get there. The travel cost was very difficult to manage." Female, Rawalpindi city 


\section{District specific Donors, Projects and Implementing partners}

\begin{tabular}{|c|c|c|}
\hline Donor & Program/ Project Title & Implementing Partner \\
\hline \multirow{2}{*}{$\begin{array}{l}\text { Bill and Melinda } \\
\text { Gates Foundation }\end{array}$} & $\begin{array}{l}\text { Building Blocks for Family Planning in Pakistan - Developing a Costed } \\
\text { Implementation Plan for Sindh and Punjab, 2013-2015 }\end{array}$ & Pathfinder International \\
\hline & $\begin{array}{l}\text { Landscape Analysis of the Family Planning Situation in Pakistan, 2015- } \\
2016\end{array}$ & Population Council \\
\hline \multirow{2}{*}{$\begin{array}{l}\text { The David \& Lucile } \\
\text { Packard } \\
\text { Foundation }\end{array}$} & $\begin{array}{l}\text { Achieving MDG5 - Continuing Momentum, Building Champions, 2012- } \\
2015\end{array}$ & Shirkat Gah Women Resource Centre \\
\hline & $\begin{array}{l}\text { Strengthening and Sustaining Postpartum Family Planning in Pakistan, } \\
\text { 2013-2015 }\end{array}$ & JHU - JHPIEGO \\
\hline USAID & DELIVER Project, 2008-2016 & $\begin{array}{l}\text { The Planning Commission of Pakistan, The Ministry of Health } \\
\text { (MOH), Provincial and Regional Departments of Health and } \\
\text { Population, UNFPA, and NGOs }\end{array}$ \\
\hline \multirow[b]{2}{*}{ UNFPA } & $\begin{array}{l}\text { Capacity Building of Female Service Providers Enhanced in Family } \\
\text { Planning, 2014-2017 }\end{array}$ & $\begin{array}{l}\text { Population Welfare Departments } \\
\text { MNCH Programs } \\
\text { LHWs Program }\end{array}$ \\
\hline & $\begin{array}{l}\text { Advocacy for Universal Access to Reproductive Health and to Integrate in } \\
\text { Provincial Health Policies, Plans and Budgetary Frameworks, 2012-2017 }\end{array}$ & $\begin{array}{l}\text { Population Welfare Departments } \\
\text { Population Council } \\
\text { Pathfinder } \\
\text { Ministry of National Health Services, Regulations and } \\
\text { Coordination }\end{array}$ \\
\hline WHO & $\begin{array}{l}\text { Providing Technical Assistance to the Country for the Development of a } \\
\text { Unified Care Providers Manual based on the WHO Handbook on FP }\end{array}$ & $\begin{array}{l}\text { Ministry of National Health Services Coordination and } \\
\text { Regulation } \\
\text { MNCH programs } \\
\text { UNFPA, Population Council, GIZ, USAID, etc. }\end{array}$ \\
\hline $\begin{array}{l}\text { Large Anonymous } \\
\text { Donor (LAD) }\end{array}$ & $\begin{array}{l}\text { Increasing Access to and Use of Long Term Methods of FP and PAC } \\
\text { Services in Pakistan, 2014-16 }\end{array}$ & Greenstar Social Marketing \\
\hline
\end{tabular}

